\title{
Homeless encampments: connecting public health and human rights
}

\author{
Nicholas Olson ${ }^{1} \cdot$ Bernadette Pauly ${ }^{2}$ (1)
}

Received: 24 June 2021 / Accepted: 22 September 2021 / Published online: 2 November 2021

(c) The Author(s), under exclusive licence to The Canadian Public Health Association 2021

\begin{abstract}
The COVID-19 pandemic is exacerbating longstanding issues related to homelessness, including lack of affordable housing, unemployment, poverty, wealth inequality, and ongoing impacts of colonization. Homelessness is often accompanied by narratives rooted in individual blame, criminalization, and reinforcement of substance use and mental health-related stigma. Visible homelessness, in the form of encampments, is a manifestation of government policy failures that neglect to uphold the human right to housing, and demonstrate eroding investments in affordable housing, income and systemic supports. Encampments make visible that some in our community lack basic determinants of health such as food, water, sanitation, safety, and the right to self-determination. In order for public health to effectively and equitably promote health and enact commitments to social justice, we argue that public health must adopt a human rights approach to housing and to homeless encampments. Embracing a human rights perspective means public health would advocate first and foremost for adequate housing and other resources rooted in self-determination of encampment residents. In the absence of housing, public health would uphold human rights through the provision of public health resources and prohibition on evictions of encampments until adequate housing is available.
\end{abstract}

\section{Résumé}

La pandémie de COVID-19 exacerbe des problèmes de longue date liés au sans-abrisme, dont le manque de logements abordables, le chômage, la pauvreté, l'inégalité de richesse et les impacts continus de la colonisation. Le sans-abrisme s'accompagne souvent de discours narratifs ancrés dans le blâme personnel, la criminalisation et le renforcement de la stigmatisation de l'usage de substances et des troubles de santé mentale. Le sans-abrisme visible, qui prend la forme des campements, est un constat d'échec des politiques gouvernementales qui négligent de faire respecter le droit fondamental au logement, et il démontre l'érosion des investissements dans les logements abordables, le soutien du revenu et le soutien systémique. Les campements rendent visible le fait qu'il manque à certains membres de la collectivité les déterminants de base de la santé, comme la nourriture, l'eau, les installations sanitaires, la sécurité et le droit à l'autodétermination. Pour que la santé publique fasse efficacement et équitablement la promotion de la santé et pour qu'elle donne suite à ses engagements envers la justice sociale, nous faisons valoir qu'elle doit aborder le logement et les campements de sans-abri selon une approche fondée sur les droits humains. L'adoption d'une perspective axée sur les droits humains signifie que la santé publique doit d'abord et avant tout plaider en faveur de ressources, dont des logements adéquats, ancrées dans l'autodétermination des résidents des campements. En l'absence de logements, la santé publique devrait faire respecter les droits humains par la mise à disposition de ses ressources et par l'interdiction des expulsions des campements jusqu'à ce que des logements adéquats deviennent disponibles.

Keywords Public health $\cdot$ Encampments $\cdot$ Tent cities $\cdot$ Human rights $\cdot$ Housing $\cdot$ Homelessness

Mots-clés Santé publique $\cdot$ campements $\cdot$ villages de tentes $\cdot$ droits de l'homme $\cdot$ logement $\cdot$ sans-abrisme

Bernadette Pauly

bpauly@uvic.ca

1 School of Public Health and Social Policy, University of Victoria, Victoria, BC, Canada

2 Canadian Institute for Substance Use Research (CISUR), University of Victoria, 2300 McKenzie Ave, Victoria, BC V8N 5M8, Canada
The COVID-19 pandemic has resulted in widespread public and private sector restrictions and a global economic crisis that has intensified existing inequities such as lack of affordable housing, unemployment, longstanding poverty and wealth inequality, and the ongoing impacts of colonization. During COVID-19, there has been an increase in 
visible homelessness particularly in the form of encampments in urban centres (Lorinc, 2020). The rise of visible homelessness is often paired with troubling public narratives that perpetuate stereotypes, stigma, and discrimination related to crime, substance use, mental health, and poverty, thus intensifying the trauma endured by people experiencing homelessness. Such narratives are often used to justify the displacement of encampments while ignoring that encampment residents lack basic determinants of health and human rights to water, sanitation, food, and shelter. Public health officials are often at the nexus of these controversies and heightened public tensions. In this commentary, we outline the importance and relevance of a human rights approach for informing and bolstering public health responses to homelessness.

Public health is rooted in health equity and social justice, goals (Beauchamp, 1976) that are operationalized in public health standards and competencies (Edwards \& Davison, 2008; Public Health Agency of Canada, 2008). Health equity is concerned with the impacts of social conditions on health and promotion of equitable conditions for health with an emphasis on the involvement and engagement of people impacted by inequities (Braveman, 2010). As such, health equity is inextricably linked to human rights including access to adequate housing, food, income, and self-determination as requirements for health justice and enshrined in International Human Rights Covenants (Braveman, 2010; Meier et al., 2018). The 2019 Canadian Housing Strategy Act specifically recognizes that (a) "the right to adequate housing is a fundamental human right affirmed in international law" and (b) "housing is essential to inherent dignity and well-being of the person and to building sustainable and inclusive communities" (Government of Canada, 2019, p. 2). This recognition is echoed in the National Protocol for Homeless Encampments in Canada (National Protocol) outlining the importance of housing as a human right and a human rights approach to homelessness (Farha \& Schwan, 2020). Ongoing homelessness and failure to implement these policies is contributing to poor health and premature death for homeless persons (Centre for Equality Rights in Accommodation and National Right to Housing Network, 2021). Recognizing the right to housing and protecting human rights are central to public health commitments to health equity and social justice.

In the absence of housing, COVID-19 guidelines for encampments such as those released by the National Collaborating Centre for Environmental Health (NCCEH) (Yehia, 2020) and the best practices released by the British Columbia (BC) Ministry of Health (BCCDC, 2020) offer public health guidance, but fall short of adopting a human rights approach. This shortcoming raises the risk of these guidelines being co-opted and used to justify stigmatization, displacement, criminalization, and inaction due to a lack of focus on human rights to basic determinants of health (Farha
\& Schwan, 2020). Without a strong public health and human rights approach, public health can be weaponized in service of societal narratives that problematize homelessness as an individual failing, a disease or crime rather than a structurally produced problem with consequences of trauma and violence.

\section{Dominant discourses surrounding encampments}

Encampments are often portrayed publicly through three closely linked narratives-individual deficiencies, mental health and substance use, and criminalization - which often inform governmental, community, and non-profit responses to these sites. Despite the fact that people experiencing homelessness are no more likely to break the law, except for laws that punish people for living outdoors (Rankin, 2019), community opposition to encampments is often based in fears of increasing crime rates and jeopardizing public health and safety (Loftus-Farren, 2011).

For example, court cases, such as British Columbiav. Adamson BCSC 1245 (2016), have cited "health and safety risks" such as fire hazards, violence, criminal activities, human waste, pests, substance use, and used needles as reasons to call for dismantling of an encampment. When public health is co-opted by narratives of public safety, it denies the varied human rights and public health concerns raised by residents of encampments that often focus on deficiencies in the determinants of health, such as housing, food and sanitation.

The neoliberal notion that encampments exist because of individual shortcomings ignores how encampments are instead sites of public health deficiencies rooted in government policies related to lack of housing, sanitation, food storage, inadequate incomes, and other resources. In May 2020, a BC ministerial order cited public health concerns of COVID-19 transmission, public safety, and increases in crime when forcing residents out of three public spaces in Vancouver and Victoria (Kines, 2020). Although displacement of the three encampments was accompanied by offers of hotel-style spaces, the process ignored rights to selfdetermination of encampment residents and forced closure of these encampments despite lack of adequate and sufficient spaces to move everyone indoors.

Instead of citing concerns of safety, crime, mental health, and substance use as public health rationale for displacement of encampments, public health officials should recognize encampment residents as rights holders-people with a right to housing, self-determination and basic determinants of health. This would ensure public health responses are rooted in social justice and bolstered by human rights. 


\section{Public health and "a human rights approach"}

The National Protocol outlines eight principles, including the right to housing and how to uphold human rights in the absence of housing (Farha \& Schwan, 2020). These eight principles can be used to squarely orient public health guidelines, such as those identified earlier, to housing as a human right and a public health approach based on protection of human rights and promotion of health equity and social justice.

The first two principles of the National Protocol recognize those who are homeless as holders of human rights, and the priority of appropriate housing as determined by encampment residents themselves as the only adequate, human rights-centred response to encampments (Farha \& Schwan, 2020). As such, public health must acknowledge those who are living unsheltered in encampments as having the fundamental right to housing that is contained in human rights law and recognized as an essential basic determinant of health. Principle 2 of the National Protocol states that residents of encampments must be able to participate in decisions that affect their health and well-being as an "exercise of agency, autonomy, and self-determination" (Farha \& Schwan, 2020, p. 16). The public health guidelines laid out by the BC Ministry of Health and the NCCEH neglect to foreground self-determination and the involvement of encampment residents as a fundamental requirement of human rights and core principle of health equity. For example, offers of shelter spaces are often refused by people experiencing homelessness because of lack of privacy and safety (Cohen et al., 2019). Further, any decisions surrounding encampment service provision, harm reduction, hygiene and sanitation, and potential relocation should be centred around the perspectives of people living in encampments and acknowledge that "residents are experts in their own lives", including how best to promote and protect health (Farha \& Schwan, 2020).

Principles 3, 4, and 5 relate to human rights in the context of evictions and relocations. The BC Ministry of Health and NCCEH public health guidelines acknowledge the increased risk of infectious disease spread and other public health and safety risks that come with displacement of encampments. However, this acknowledgement falls short of a human rights perspective that prohibits forcible evictions "in all circumstances", including but not limited to public health emergencies such as COVID-19 (Farha \& Schwan, 2020). Forcible displacement results in a myriad of harms, including trauma and disconnection from services.

The sixth principle of the National Protocol requires governments to "ensure encampments meet basic needs of residents consistent with human rights" (Farha \& Schwan, 2020). In the absence of providing adequate housing as determined by encampment residents, a public health and human rights response would ensure access to basic determinants of health such as food, water, sanitation, and garbage disposal. While the BC Ministry of Health and the NCCEH guidelines advocate for the timely provision of such resources, when removed from a rights-based approach these guidelines risk being used for enforcement and displacement when public health standards are not met, instead of protecting rights to basic determinants of health.

Last, principles 7 and 8 speak to the importance of ensuring respect and dignity for all encampment residents with specific attention to Indigenous Peoples. While the BC Ministry of Health refers to human rights and Indigenous rights in their encampment guidelines, the NCCEH guidelines do not mention Indigenous Peoples or Canada's ongoing history of colonization that has deprived Indigenous people of land and resources and led to an overrepresentation of Indigenous people among those who are homeless. Guidelines that neglect to meaningfully frame recommendations from these perspectives risk inadequate public health responses and actions that violate human rights and are complicit in ongoing processes of colonization.

The eight principles of the National Protocol offer examples of how public health responses to encampments can protect public health and uphold human rights, first and foremost through access to adequate housing as defined by encampment residents, and in absence of that, through the provision of public health resources and supports to address basic determinants of health.

\section{Human rights claims and public health assertions}

Dominant narratives place the blame for systemic deficiencies onto residents of encampments to rationalize displacement and eviction of encampments. However, encampments are manifestations of government and public health deficiencies, specifically the "failure to successfully implement the right to adequate housing" (Farha \& Schwan, 2020) and protect rights to basic determinants of health.

According to the Pan American Health Organization (n.d.), effective public health "requires explicit and concrete efforts to promote and protect human rights and dignity". The BC Ministry of Health and NCCEH guidelines are meant to address public health concerns related to encampments in the context of COVID-19. However, in order to do so effectively, they must pair public health with human rights approaches. While these guidelines include "human rights considerations" and maintain that adequate housing is preferable to people living in encampments, meaningfully taking up a human rights approach would begin by firmly 
stating a right to housing and respecting people experiencing homelessness as rights holders in ensuring adequate housing options and basic determinants of health. To enact public health commitments of health equity and social justice, public health guidance regarding homeless encampments should integrate human rights principles as outlined above from the National Protocol.

Author contributions All authors contributed to the study conception and design. The first draft of the manuscript was written by Nicholas Olson and all authors commented on previous versions of the manuscript. All authors read and approved the final manuscript.

Funding This study was funded by Bernie Pauly's Island Health Scholar in Residence.

\section{Declarations}

Ethics approval This article does not contain any studies with human participants or animals performed by any of the authors.

Conflict of interest The authors declare no competing interests.

\section{References}

Beauchamp, D. E. (1976). Public health as social justice. Inquiry, 13(1), 3-14.

Braveman, P. (2010). Social conditions, health equity, and human rights. Health and Human Rights: An International Journal, 12(2).

British Columbia Centre for Disease Control (BCCDC). (2020). Response to homeless encampments health issues in the context of COVID-19: guidelines and best practices. Resource Document. https://www.qathet.ca/wp-content/uploads/2020/06/COVID19Homeless-Encampment-Responses-Resource-final.pdf. Accessed 17 May 2021.

British Columbia v. Adamson, 1245 (BCSC 2016). https://www.escr-net.org/ caselaw/2010/victoria-city-v-adams-2009-bcca-563-2008-bcsc-1363

Centre for Equality Rights in Accommodation and National Rights to Housing Network. (2021). The rights to life, protection of the home and non discrimination in Canada. Assessing the Housing \& Homelessness Crisis in Accordance with Articles 2, 6, 17 \& 26 of the ICCPR. Submission to UN Human Rights Committeee, $132^{\text {nd }}$ Session. For the List of Issues prior to reporting for Canada's $7^{\text {th }}$ periodic review.

Cohen, R., Yetvin, W., \& Khadduri, J. (2019). Understanding encampments of people experiencing homelessness and community responses. U.S. Department of Housing and Urban Development.
https://www.huduser.gov/portal/publications/UnderstandingEncampments.html. Accessed 17 June 2021.

Edwards, N. C., \& Davison, C. M. (2008). Social justice and core competencies for public health. Canadian Journal of Public Health, 99(2), 130-132.

Farha, L., \& Schwan, K. (2020). A human rights approach: A national protocol for homeless encampments in Canada. Resource Document. UN Special Rapporteur on the Right to Housing. Resource Document. https://www.make-the-shift.org/wp-content/uploads/ 2020/04/A-National-Protocol-for-Homeless-Encampments-inCanada.pdf. Accessed 17 May 2021.

Government of Canada. (2019). National Housing Strategy Act. https:// laws-lois.justice.gc.ca/eng/acts/N-11.2/FullText.html.

Kines, L. (2020). Province orders dismantling of Pandora, Topaz camps; residents moving to hotels. Times Colonist. April 25, 2020. https://www.timescolonist.com/news/local/province-ordersdismantling-of-pandora-topaz-camps-residents-moving-to-hotels1.24124339. Accessed 17 May 2021.

Loftus-Farren, Z. (2011). Tent cities: An interim solution to homelessness and affordable housing shortages in the United States. California Law Review, 99, 1037-1081.

Lorinc, J. (2020). Tents housing the homeless are popping up around Toronto. Here's what the city is doing about it. Toronto Star. May 15, 2020. https://www.thestar.com/news/gta/2020/05/14/tents-housingthe-homeless-are-popping-up-around-toronto-heres-what-the-city-isdoing-about-it.html. Accessed 17 May 2021.

Meier, B. M., Evans, D. P., Kavanagh, M. M., Keralis, J. M., \& ArmasCardona, G. (2018). Human rights in public health: Deepening engagement at a critical time. Health and Human Rights, 20(2), 85-92.

Pan American Health Organization. (n.d.). The links between health and human rights. https://www3.paho.org/hq/index.php? Accessed 17 May 2021. option=com_content\&view=article\&id $=1348$ :links-between-heath-human-rights\&Itemid=643\&lang=fr. Accessed 17 May 2021.

Public Health Agency of Canada. (2008). Core competencies for public health in Canada: Release 1.0. Resource Document. https:// www.canada.ca/content/dam/phac-aspc/documents/services/ public-health-practice/skills-online/core-competencies-publichealth-canada/cc-manual-eng090407.pdf. Accessed 17 May 2021.

Protecting the right to housing in the context of the COVID-19 outbreak. (2020). https://www.ohchr.org/EN/Issues/Housing/Pages/ COVID19RightToHousing.aspx. Accessed 17 May 2021.

Rankin, S. K. (2019). Punishing homelessness. New. Criminal Law Review, 22(1), 99-135. https://doi.org/10.1525/nclr.2019.22.1.99

Yehia, J. (2020). Environmental public health guidance for encampments during the COVID-19 pandemic. Resource Document. National Collaborating Centre for Environmental Health. https:// ncceh.ca/documents/guide/environmental-public-health-guida nce-encampments-during-covid-19-pandemic. Accessed 17 May 2021.

Publisher's note Springer Nature remains neutral with regard to jurisdictional claims in published maps and institutional affiliations. 